Chem. Chem. Technol., 2020,

Vol. 14, No. 1, pp. 70-75

Chemistry

\title{
THE PRODUCTION OF SILVER NANOPARTICLES AND THEIR EFFECT ON SULFATE REDUCING BACTERIA UNDER STEEL MICROBIAL CORROSION
}

\author{
Margarita Skiba1, Iryna Kurmakova ${ }^{2,}{ }^{凶}$, Olena Bondar $^{2}$, Natalia Demchenko $^{2}$, \\ Viktoria Vorobyova ${ }^{3}$
}

https://doi.org/10.23939/chcht14.01.070

\begin{abstract}
The production of silver nanoparticles was carried out in an aqueous medium treated by discharge of the contact non-equilibrium low-temperature plasma in the presence of sodium alginate $(1.25-5.0 \mathrm{~g} / \mathrm{l})$. The formation of silver metal particles (to $100 \mathrm{~nm}$ ) was confirmed by X-ray diffraction and IR spectroscopy analysis. The obtained colloidal solutions of silver nanoparticles lead to the formation of thinner biofilm under microbial corrosion of mild steel, initiated by sulfate reducing bacteria of Desulfomicrobium genus. Bacteria of Desulfovibrio genus appeared to be resistant to silver nanoparticles.
\end{abstract}

Keywords: plasma-chemical, nanoparticles, silver, sodium alginate, sulfate reducing bacteria, biocorrosion.

\section{Introduction}

The combination of optical and antimicrobial properties of silver nanoparticles gives an opportunity of practical application thereof in various spheres of human activity. Silver nanoparticles can be applied in different ways, also as doping agent in different corrosion inhibitor media [1].

Different methods have been used in the production of nano-sized metallic silver $(\mathrm{Ag})$ particles with different morphologies and sizes [2]. With all the benefits, most of the existing methods require the use of reducing reagents, that are corrosion aggressive.

\footnotetext{
${ }^{1}$ Ukrainian State Chemical-Engineering University,

8, Gagarin Ave., 49005 Dnipro, Ukraine

${ }^{2}$ T.H. Shevchenko National University "Chernihiv Colehium",

53, Hetmana Polubotka St., 14013 Chernihiv, Ukraine

${ }^{3}$ National Technical University of Ukraine "Igor Sikorsky Kyiv

Polytechnic Institute",

37, Peremogy Ave., 03056 Kyiv, Ukraine

凶i.kurmakova@gmail.com

(c) Skiba M., Kurmakova I., Bondar O., Demchenko N.,

Vorobyova V., 2020
}

Therefore, developing new methods of the production of stable silver nanoparticles solutions, using minimal reagents, is now a crucial task. One of the innovative and environmentally safe methods for production of nanosized compounds is the use of plasma discharges of various configurations [3]: plasma discharge generated between the electrodes immersed in the liquid, at gasliquid phase interface at reduced pressure, and plasma under the atmospheric pressure at the interaction with a liquid.

Among plasma-chemical discharges, contact nonequilibrium low-temperature plasma (CNP) is a promising option from the practical application standpoint [4]. Plasma discharge is generated between the electrode in the gaseous phase and surface of the liquid where the other electrode is located. Therefore, chemical transformations at the phase interface are conditioned by the combined effect of electrochemical oxidation-reduction; initiated photolysis reactions, UV radiation; and flow of charged particles from the gaseous phase to the surface of the liquid medium. By varying the composition of liquid phases, it is possible, in some degree, to manage the paths of chemical transformations and composition of obtained products [4]. In the previous works the authors showed the efficiency of using the contact non-equilibrium lowtemperature plasma in comparison with the conventional method of chemical reduction in solutions and photochemical deposition [5].

The research of silver nanoparticles effect on sulfate reducing bacteria (SRB) is particularly interesting from scientific and practical standpoint, as SRB are the most aggressive compounds of natural and man-caused microbial communities causing microbial metal corrosion [6].

The aim of this paper is to obtain silver nanoparticles using the method of plasma-chemical discharge and study their effect on the bacteria of Desulfovibrio and Desulfomicrobium genera under steel microbial corrosion. 


\section{Experimental}

\subsection{Preparation of Silver Nanoparticles (NPs)}

Silver nitrate $(99.8 \%$, Kishida) was purchased from Merck Co. Ltd. (Darmstadt, Germany). An aqueous solution of silver nitrate at different concentrations was prepared using ultrapure water (Direct-Q UV, Millipore). It was utilized as starting materials without further purification.

The research was carried out at the laboratory of plasma-chemical technologies of the Ukrainian State Chemical Technology University (Ukraine) on a laboratory installation of a discrete type with a reactor volume of $0.1 \mathrm{dm}^{3}$ (Fig. 1). Cathode (diameter $4 \mathrm{~mm}$, $18 \mathrm{H} 10 \mathrm{~T}$ stainless steel electrodes) was located in the liquid part, with the anode (diameter $2.4 \mathrm{~mm}$ ) placed at the distance of $10 \mathrm{~mm}$ from the solution surface. The volume of the solution in the reactor was $70 \mathrm{ml}$. Cooling of reaction mixture was provided by continuous circulation of cold water. The pressure in the reactor was maintained at $80 \pm 4 \mathrm{kPa}$. For obtaining plasma discharge the voltage of $500-1000 \mathrm{~V}$ was applied to the electrodes. The current strength was maintained at the level of $120 \pm 6 \mathrm{~mA}$. The duration of plasma processing of solutions ranged from 1 to $5 \mathrm{~min}$.

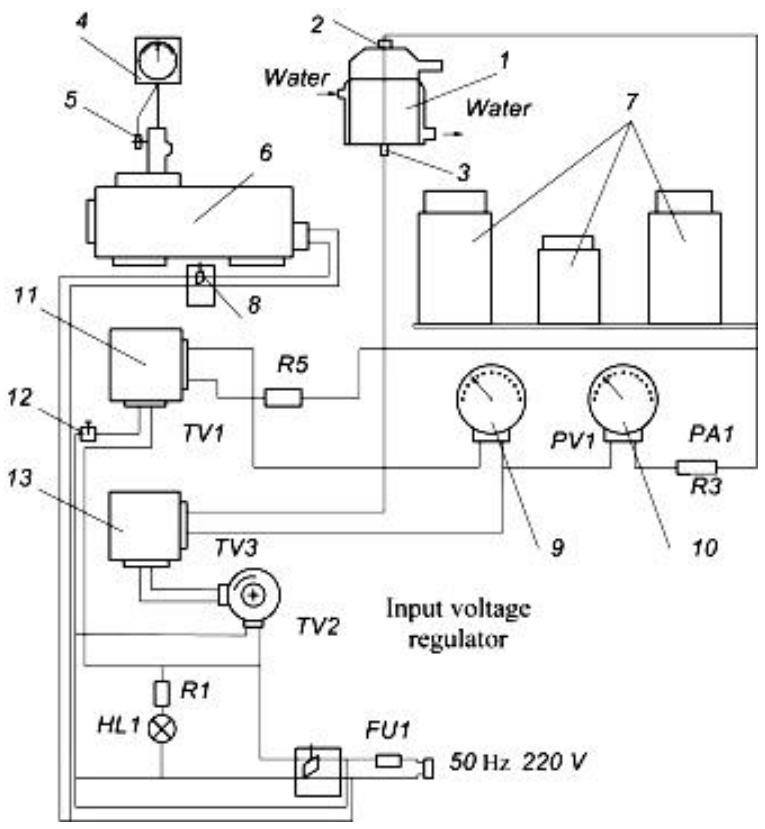

Fig. 1. The circuit diagram discharge of the installation for plasma-chemical treatment of water solutions: reactor (1); electrodes (2, 3); vacuum gauge (4); crane (5); pump (6); filtering elements (7); switch (8); voltmeter (9); ammeter (10); firearm transformer (11); switch (12) and voltage transformer (13)

\subsection{Characterization Techniques of Silver Nanoparticles}

Spectra of colloidal solutions were obtained by means of spectrophotometer UV-5800PC using quartz cuvettes in the wavelength range of 190-700 nm (FRU, China). Microphotographs of nanoparticles and particle sizes were obtained on scanning microscope JEOL JSM6510LV (JEOL, Tokyo, Japan). Disperse phase of the solution, obtained as a result of plasma-chemical treatment of the solution and dried in the air at $298 \mathrm{~K}$, was studied with the use of X-ray diffractometer Ultima IV Rigaku.

\subsection{SEM-Image of Colloidal Solution}

SEM-image of colloidal solution of silver was obtained by plasma-chemical method with addition of sodium alginate $\left(C_{\text {(silver nitrate) }}=0.5 \mathrm{~g} / 1, C_{\text {(sodium alginate) }}=\right.$ $=5.0 \mathrm{~g} / \mathrm{l}, I=120 \mathrm{~mA}, P=0.08 \mathrm{MPa}, \tau=5 \mathrm{~min})$.

\subsection{Microbiological Tests}

Sulfate-reducing bacteria strains Desulfovibrio sp. M.4.1 and Desulfomicrobium sp. TC4 were used as test microorganisms. Strain Desulfovibrio sp. M.4.1 was previously gathered by us from corroded iron coating of the subterranean gas pipeline [7]; Desulfomicrobium $s p$. TC4 was bought from the collection of the department of general and soil microbiology, D. K. Zabolotny Institute of Microbiology and Virology, the National Academy of Sciences of Ukraine. Strain Desulfomicrobium sp. TC4 was gathered from the corroded fouling of central heating brass pipelines. Both bacteria strains belong to gramnegative bacteria.

The number of the SRB, inoculated to the correspondent liquid selective medium Postgate "B", was calculated using the Most Probable Number method [8]. Postgate " $\mathrm{B}$ " medium [9] composition per liter: $\mathrm{KH}_{2} \mathrm{PO}_{4}$ $0.5 \mathrm{~g} ; \mathrm{NH}_{4} \mathrm{Cl}-1.0 \mathrm{~g} ; \mathrm{CaSO}_{4} \cdot 2 \mathrm{H}_{2} \mathrm{O}-1.0 \mathrm{~g} ; \mathrm{MgSO}_{4}-$ $2.0 \mathrm{~g}$; calcium lactate $-3.5 \mathrm{~g}$; yeast extract $(5 \%)-10 \mathrm{ml}$; $\mathrm{FeSO}_{4} \cdot 7 \mathrm{H}_{2} \mathrm{O}(5 \%$ solution in $1 \% \mathrm{HCl})-10 \mathrm{ml}$; ascorbic acid $(5 \%)-2 \mathrm{ml} ; \mathrm{NaHCO}_{3}(5 \%)$ - in quantity for $\mathrm{pH} 7.5$. The acidity was measured with $\mathrm{pH}$-meter/ionomer $\mathrm{pH} / \mathrm{ION} 340 \mathrm{i}$.

The biofilm cells, which appeared on the surface of steel coupons during tests, were gathered into the fixed volume $(20 \mathrm{ml})$ of $0.1 \mathrm{~N}$ phosphate buffer $(\mathrm{pH}=7)$ with the help of ultrasound with the frequency of $25 \mathrm{kHz}(30 \mathrm{~s})$ twice with the 60 s interval using UZM-003/n. The resulting swab was used in cultivating and calculating the adhered bacteria cells [8].

The concentration of biogenic hydrogen sulfide was measured with iodometric titration. 


\subsection{Corrosion Tests}

The corrosion tests were performed with the help of gravimetric method [10]. The mild steel St3ps coupons (surface area $0.002 \mathrm{~m}^{2}$ ) were used. Before being placed in the corrosive medium (model medium Postgate "B" with sulfate-reducing bacteria), the steel coupons were cleaned with acetone, and weighed with analytical scales accurate to $5 \cdot 10^{-5} \mathrm{~g}$. After immersing in the corrosive medium for 10 days under the temperature of $301 \pm 1 \mathrm{~K}$ (optimal temperature for sulfate-reducing bacteria growth), the coupons were weighed. Corrosion rate was calculated according to the formula $k_{m}=\Delta m /(S \cdot \tau)$, where $\Delta m$ is a weight loss, $\mathrm{g} ; S$ is an area, $\mathrm{m}^{2} ; \tau$ is an exposure time, $\mathrm{h}$.

Corrosion inhibition coefficient was calculated as: $\gamma=k / k^{\prime}$, where $k$ and $k^{\prime}$ is the corrosion rate without and with the inhibitor (100 mg/l colloidal solution of silver), respectively.

The inhibition efficiency (IE, \%) was calculated using the following equation: $\mathrm{IE}_{\%}=(1-1 / \gamma) \cdot 100 \%$.

Statistical analysis of the experimental data (the corrosion rate) for the reliability level $95 \%$ was conducted with the help of Microsoft Excel. The experiment was conducted three times.

Redox potential $(E, \mathrm{mV})$ of the corrosive medium was calculated using the meter of redox potential and recording device LabQuest 2 (Vernier Software \& Technology). The comparison electrode was chlorine silver. The measurement error was $\pm 0.5 \mathrm{mV}$.

\section{Results and Discussion}

To evaluate the properties of nanoparticles colloidal solutions, the method of optical spectroscopy [11] is widely used. According to the Mie-Drude theory, the optical properties of colloidal solutions of silver nanoparticles are characterized by the presence of the pronounced resonance absorption band of the surface plasmon resonance (SPR) in the range of 395-465 $\mathrm{nm}$ [12].

The effect of sodium alginate concentration and duration of processing by plasma discharge on the production of silver nanoparticles was studied. The formation of silver colloidal solutions in the presence of stabilizer is characterized by the presence of the peak $\lambda_{\max }=400-440 \mathrm{~nm}$ in the spectra. An increase in concentration of sodium alginate from 1.25 to $5.0 \mathrm{~g} / \mathrm{l}$ (Fig. 2 , curves 2,3) contributes to sharp increase in SPR peak intensity and its noticeable shift $(\sim 40 \mathrm{~nm})$ to the shortwave region. This can be explained by the formation of more silver nanoparticles and/or reduction of their size. The content of sodium alginate in the reaction medium $(1.25-5.0 \mathrm{~g} / \mathrm{l})$ is sufficient for nanoparticles stabilization.

The possible reason is that the increase in quantity of carboxyl and hydroxyl groups of sodium alginate assists in complexation between $\mathrm{Ag}^{+}$and molecular matrix of the polymer, apart from the fact that higher quantity of hydroxyl groups promotes the reduction of $\mathrm{Ag}^{+}$(Fig. 3) [13].

The interaction of $\mathrm{AgNP}_{\mathrm{S}}$ with sodium alginate is confirmed by the analysis of IR spectroscopy (Fig. 4). In the AlgNa alginate spectra, the peak within 3200 $3600 \mathrm{~cm}^{-1}$ corresponds to deformation oscillations of the hydroxyl group bond. The peaks at 1412 and $1591 \mathrm{~cm}^{-1}$ characterize $-\mathrm{COO}-$ symmetric and asymmetric deformation oscillations, respectively. The small and expanded peak within $1327-1370 \mathrm{~cm}^{-1}$ can be explained by the $\mathrm{C}-\mathrm{O}$ bond. Two peaks at the wavelengths of 1016.5 and $1078 \mathrm{~cm}^{-1}$ are characterized by deformation oscillations of $\mathrm{C}=\mathrm{O}$ and $\mathrm{C}-\mathrm{O}-\mathrm{C}$. Absorption peaks within $1030-1200 \mathrm{~cm}^{-1}$ are characteristic of natural polysaccharide.

When comparing the alginate spectrum with $\mathrm{AgNP}_{\mathrm{S}} / \mathrm{Alg}$, one can observe a significant shift of the wave position from $1591 \mathrm{~cm}^{-1}$ for alginate to $1640 \mathrm{~cm}^{-1}$ for $\mathrm{AgNP}_{\mathrm{S}}$, with a decrease in intensity. This shift confirms the interaction of oxygen carboxyl groups in the alginate structure with $\mathrm{AgNP}_{\mathrm{S}}$. The peak shift within $3200-3500 \mathrm{~cm}^{-1}$ was negligible, but the decrease in intensity was sharp. Changes in position and intensity are related to the probable interaction of $\mathrm{AgNP}_{\mathrm{S}}$ and hydroxyl groups of alginate. The single peak expanded from 1017 to $1084 \mathrm{~cm}^{-1}$ can be attributed to the chemical transformation during the reduction of $\mathrm{Ag}^{+}$to $\mathrm{Ag}^{0}$ [14].

The formation of silver metal particles is confirmed by X-ray diffraction analysis. Fig. 5 shows X-ray pattern of silver nanoparticles obtained in the presence of sodium alginate under the action of CNP for $5 \mathrm{~min}$. The conditions of experiment were as follows: concentration of silver nitrate $0.5 \mathrm{~g} / 1$ and concentration of sodium alginate $5.0 \mathrm{~g} / \mathrm{l}$. A number of different diffraction peaks at approximately $38.1^{\circ}, 44.2^{\circ}, 64.3^{\circ}$, and $77.4^{\circ}$ correspond to reflexes from (111), (200), (220), and (311) silver crystal planes, respectively, which confirms the presence of crystalline silver with the boundary-cubic structure of silver.

Dimensional characteristics of plasma-chemically obtained silver nanoparticles in the presence of sodium alginate were investigated by the method of scanning electron microscopy (Fig. 6). The results showed the presence of agglomerated and non-agglomerated particles. The average particle size of silver is up to $100 \mathrm{~nm}$.

The effect of colloidal solutions of silver nanoparticals stabilized by sodium alginate on sulfatereducing bacteria of Desulfovibrio and Desulfomicrobium genera under steel microbial corrosion in neutral watersalt Postgate "B" medium was studied. Vital activity of the studied microorganisms is ensured by sulfate reduction to hydrogen sulphide and oxidation of organic substances, which affects the change in redox potential of 
the corrosive medium. In the medium with Desulfovibrio $s p$. M.4.1 strain the value of $E$ decreases by $90 \mathrm{mV}$ (Fig. 7a) within the first 3 days, which can be explained by active corrosion and accumulation of iron oxidation products and bacteria metabolites in the solution. Then, redox potential increases due to the accumulation of biogenic hydrogen sulphide (Fig. $7 \mathrm{~b}$ ). The presence of silver nanoparticles stabilizes the oxidation-reduction

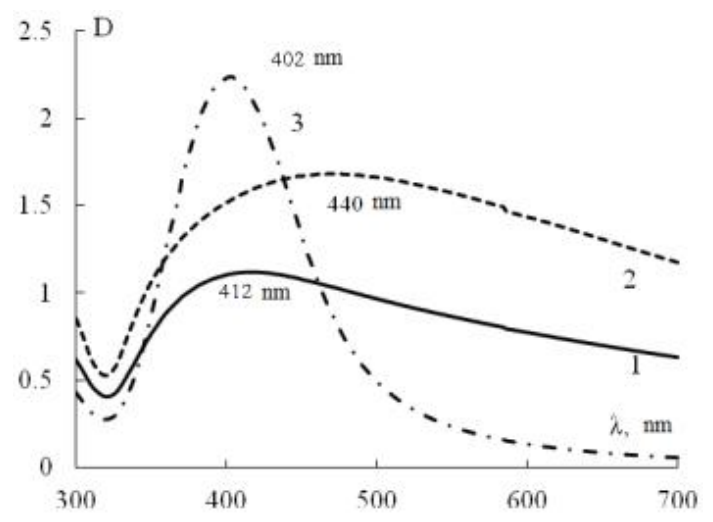

Fig. 2. Dependence of absorbance (D) of plasma-chemically obtained colloidal solution of silver on the wavelength $(\lambda)$ at various concentrations of sodium alginate, $g / 1(b)$ : $1.25(1) ; 2.5(2)$ and $5.0(3)$

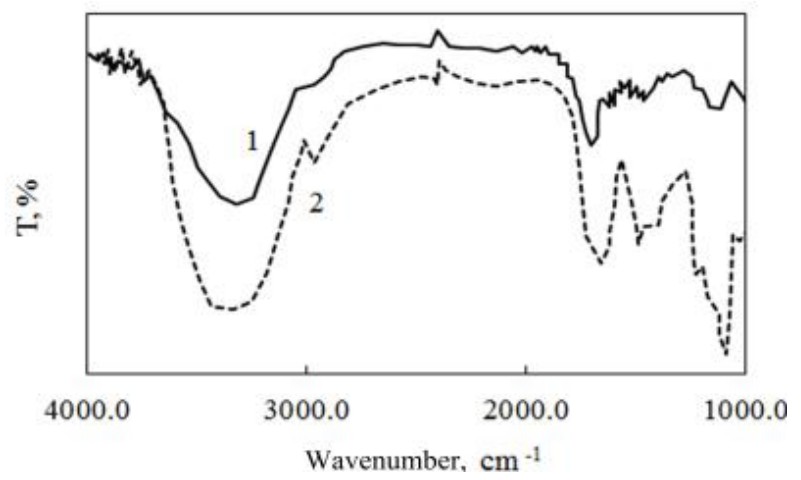

Fig. 4. IR spectroscopy of the samples: sodium alginate (1) and plasma-chemically synthesized silver nanoparticles with sodium alginate $(2)$

Fig. 6. SEM-image of colloidal solution of silver obtained by plasma-chemical method with the addition of sodium alginate $\left(C_{\text {(silver nitrate) }}=0.5 \mathrm{~g} / 1, C_{\text {(sodium alginate) }}=5.0 \mathrm{~g} / \mathrm{l}\right.$, $I=120 \mathrm{~mA}, P=0.08 \mathrm{MPa}, \tau=5 \mathrm{~min})$ system to a certain extent $-E$ fluctuates within a smaller range. However, the change in time of hydrogen sulphide concentration (Fig. 7b) and the quantitative indices of bacteria in the suspension and the biofilm (Table) indicate that the Desulfovibrio sp. M.4.1 strain reacts positively to the presence of silver nanoparticles in the corrosive medium, particularly to those, stabilized with $5.0 \mathrm{~g} / 1$ sodium alginate.

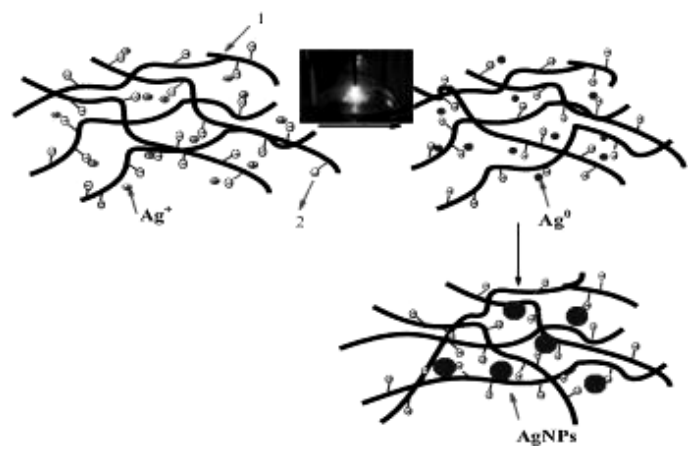

Fig. 3. Scheme of AgNP synthesis in the sodium alginate solution under the CNP discharge: alginate polymer chain (1) and carboxyl anion (2)

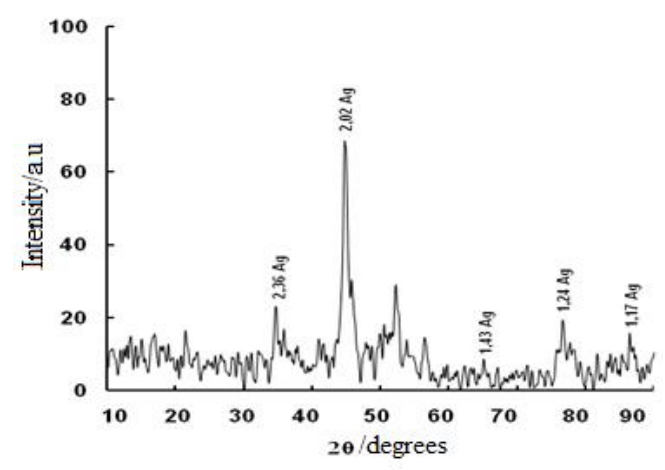

Fig. 5. X-ray diffraction pattern of plasma-chemically obtained nanoparticles of silver in the presence of sodium alginate

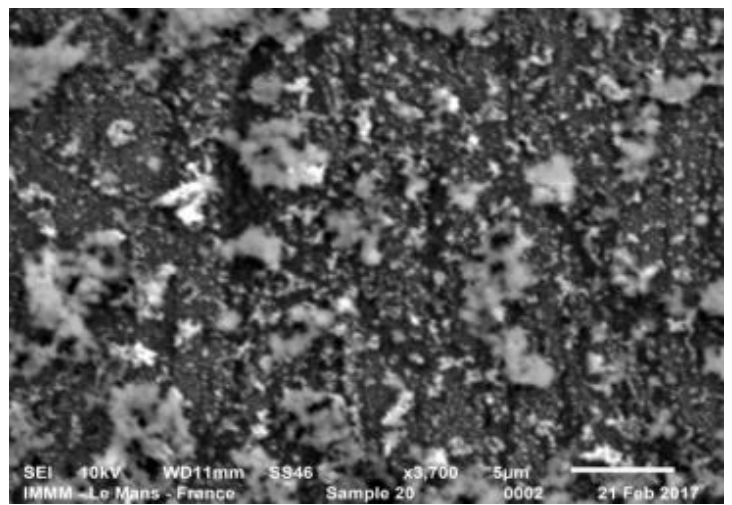


At the beginning (days 1-3), intensive $\mathrm{H}_{2} \mathrm{~S}$ production can be observed, then its concentration decreases, which can be explained by the formation of iron sulfides on the steel surface. Sulfide ion is also known to be used for constructing the component of bacteria protoplasm [15]. The number of bacteria in the suspension increases by 1-3 orders compared to the initial titre. The number of SRB in the biofilm, formed on the steel coupons surface, is by 1-2 orders less than in the corrosive medium. The main function of the biofilm, which acts as ion exchange matrix, is to provide the optimal conditions for SRB vital activities (concentration of nutrients, impediment to cationic biocides penetration, protection from antibodies and phagocyte amoebas, etc.) [6]. The formed biofilm can have certain protective properties. Under the studied conditions, the inhibition efficiency for microbial corrosion equals to $44.7-78.1 \%$.

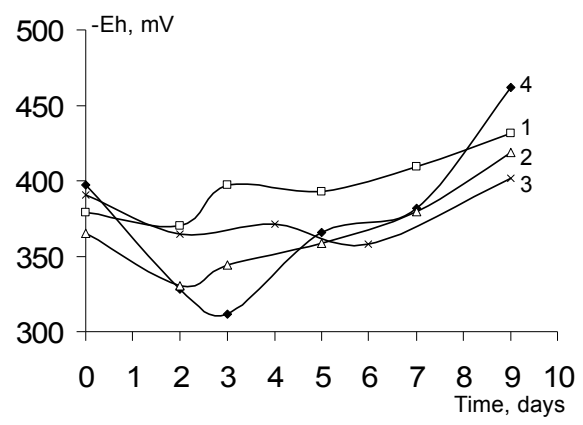

a)
In the medium with Desulfomicrobium sp. TC4 culture the similar regularity of redox potential change as with Desulfovibrio sp. M.4.1 can be observed, except for the case when colloidal silver solution, stabilized with $5.0 \mathrm{~g} / 1$ sodium alginate (Fig. 8a), is used. Substantial and sharp growth of $E$ is explained by the most intensive formation of hydrogen sulphide (Fig. $8 \mathrm{~b})$. At the same time, there is a certain decrease of a number of Desulfomicrobium sp. TC4 bacteria cells in the corrosive medium (Table). The number of bacteria cells in the biofilm is also by $1-2$ orders less than in the corrosive medium. The rate of microbial corrosion decelerates by $3.77-12.17$ times, at most when the colloidal silver solution stabilized with $5.0 \mathrm{~g} / 1$ sodium alginate is used.

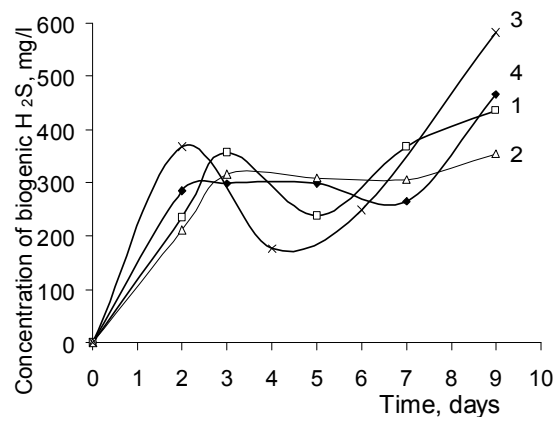

b)

Fig. 7. Correlation between redox potential (a) and concentration of biogenic $\mathrm{H}_{2} \mathrm{~S}$ (b) of Postgate "B" medium with Desulfovibrio sp. M.4.1 strain under St3ps steel microbial corrosion: with colloidal solution of silver stabilized with $1.25 \mathrm{~g} / 1$ of sodium alginate (1); with colloidal solution of silver stabilized with $2.5 \mathrm{~g} / \mathrm{l}$ of sodium alginate (2); with colloidal solution of silver stabilized with $5.0 \mathrm{~g} / \mathrm{l}$ of sodium alginate (3) and without $\mathrm{AgNP}_{\mathrm{S}} / \mathrm{Alg}(4)$

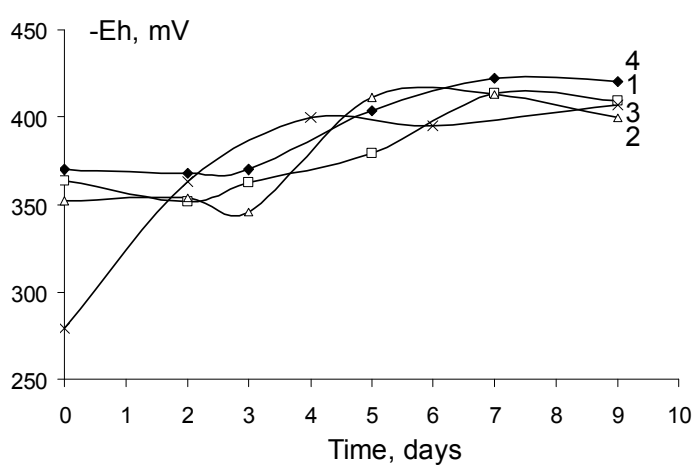

a)

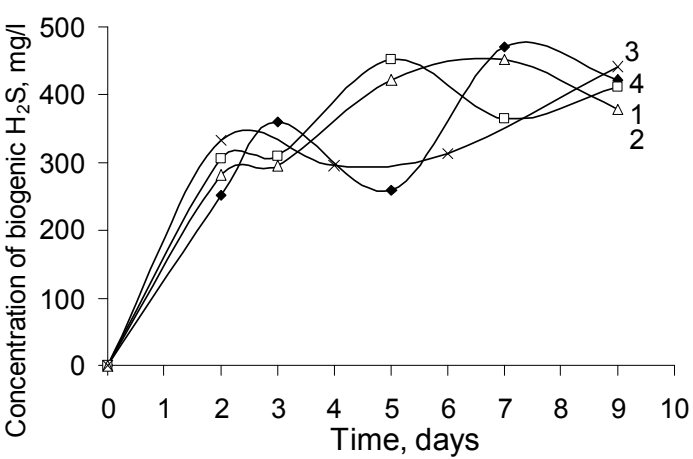

b)

Fig. 8. Correlation between redox potential (a) and concentration of biogenic $\mathrm{H}_{2} \mathrm{~S}$ (b)

Postgate "B" medium with Desulfomicrobium sp. TC4 culture under steel St3ps microbial corrosion: with colloidal solution of silver stabilized with $1.25 \mathrm{~g} / \mathrm{l}$ of sodium alginate (1); with colloidal solution of silver stabilized with $2.5 \mathrm{~g} / 1$ of sodium alginate (2); with colloidal solution of silver stabilized with $5.0 \mathrm{~g} / \mathrm{l}$ of sodium alginate (3) and without inhibitor (4) 
The effect of silver nanoparticles on corrosive (inhibition efficiency and degree of protection) and microbiological (number of bacteria cells) indices under steel St3ps microbial corrosion (initial titre of bacteria Desulfovibrio sp. M.4.1 - 10E5 cell $/ \mathrm{ml}$, Desulfomicrobium sp. TC 4 - 10E7 cell//ml)

\begin{tabular}{|c|c|c|c|c|c|c|c|c|}
\hline \multirow{2}{*}{$\begin{array}{c}\text { Concentration of } \\
\text { sodium alginate, } g / 1\end{array}$} & \multicolumn{4}{|c|}{ Desulfovibrio sp. M.4.1 } & \multicolumn{4}{|c|}{ Desulfomicrobium $\mathrm{sp}$. TC 4} \\
\hline & $\gamma$ & $\begin{array}{l}\text { IE, } \\
\%\end{array}$ & $\begin{array}{c}\text { Quantity of SRB } \\
\text { in solution, } \\
\text { cell } / \mathrm{ml}\end{array}$ & $\begin{array}{c}\text { Quantity of SRB } \\
\text { in biofilm, } \\
\text { cell } / \mathrm{cm}^{2}\end{array}$ & $\gamma$ & $\begin{array}{l}\mathrm{IE}, \\
\%\end{array}$ & $\begin{array}{c}\text { Quantity of SRB } \\
\text { in solution, } \\
\text { cell } / \mathrm{ml}\end{array}$ & $\begin{array}{c}\text { Quantity of SRB } \\
\text { in biofilm, } \\
\text { cell } / \mathrm{cm}^{2}\end{array}$ \\
\hline without $\mathrm{AgNP}_{\mathrm{S}} / \mathrm{Alg}$ & - & - & 10E6 & 10E5 & - & - & 10E6 & 10E7 \\
\hline 1.25 & 1.80 & 44.7 & 10E7 & 10E5 & 3.77 & 73.5 & 10E7 & 10E5 \\
\hline 2.5 & 3.60 & 72.4 & $10 \mathrm{E} 8$ & 10E7 & 5.12 & 80.5 & 10E7 & 10E5 \\
\hline 5.0 & 4.57 & 78.1 & 10E8 & 10E7 & 12.17 & 91.8 & 10E7 & 10E5 \\
\hline
\end{tabular}

\section{Conclusions}

Colloidal solutions of silver nanoparticles stabilized with sodium alginate and obtained with the help of plasma-chemical discharge method affect sulfate-reducing bacteria of Desulfovibrio and Desulfomicrobium genera under steel microbial corrosion. Silver nanoparticles cause the formation of thinner biofilm under the microbial corrosion of steel, initiated by sulfate-reducing bacteria of Desulfomicrobium genus. Bacteria of Desulfovibrio genus proved to be resistant to silver nanoparticles.

\section{References}

[1] Abou El-Nour K., Eftaiha A., Al-Warthan A., Ammar R.: Arab. J. Chem., 2010, 3, 135. https://doi.org/10.1016/j.arabjc.2010.04.008 [2] Krutiakov Yu., Kudrynskyi A., Olenyn A.., Lysychkyn H.: Uspekhy Khim., 2008, 77, 242.

[3] Davide M., Jenish P., Švrček V., Maguire P.: Plasma Proc. Polym., 2012, 9, 1074. https://doi.org/10.1002/ppap.201200007 [4] Pivovarov A., Kravchenko A., Tishchenko A. et al.: Russ. J. Gen. Chem., 2015, 85, 1339.

https://doi.org/10.1134/S1070363215050497

[5] Skiba M., Pivovarov A., Makarova A. et al.: East.-Eur. J. Enterpr. Techn., 2017, 6, 59. https://doi.org/10.15587/17294061.2017.118914

[6] Kozlova I., Radchenko O., Stepura L. et al.: Heokhimichna Diyalnist Microorganizmiv ta ii Prykladni Aspekty. Naukova dumka, Kyiv 2008.

[7] Demchenko N., Kurmakova I., Tretyak O.: Microbiologia i Biotechnologia, 2013, 4, 90.

[8] Egorov N.: Rukovodstvo k Praktycheskym Zanjatyiam po Microbyolohyy. Izdadelstvo Mosk. Inst., Moskva 1983.
[9] Postgate J.: The Sulfate-Reducing Bacteria. Cambridge University Press, Cambridge 1984.

[10] Fokin M., Zhigalova K.: Metody Korrozionnyh Ispytanij Metallov. Metallurgija, Moskva 1986.

[11] Stepanov A.: Zh. Techn. Fiziki, 2004, 74, 1.

[12] Baetzold R.: J. Phys. Chem. C, 2015, 119, 8299. https://doi.org/10.1021/jp512556g

[13] Ershov B., Janata E., Henglein A., Fojtik A.: J. Phys. Chem., 1993, 97, 4589. https://doi.org/10.1021/j100120a006

[14] Theivasanthi T., Alagar M.: Nano Biomed. Eng., 2012, 4, 58. https://doi.org/10.5101/nbe.v4i2.p58-65

[15] Zhang C., Wen F., Cao Y.: Proceed. $3^{\text {rd }}$ Int. Conf. on Environmental Science and Information Application Technology. China, Beijing 2011, 1177.

Received: June 27, 2018 / Revised: August 27, 2018 / Accepted: November 01, 2018

\section{ОДЕРЖАННЯ НАНОЧАСТОК СРІБЛА ТА ЇХ ВПЛИВ НА СУЛЬФАТВІДНОВЛЮВАЛЬНІ БАКТЕРÏ̈ ЗА УМОВ МІКРОБНОЇ КОРОЗІї СТАЛІ}

Анотація. Одержано водні дисперсї наночасток срібла внаслідок вивантаження контактної нерівноважної низькотемпературної плазми в присутності альгінату натрію (1,25-5,0 г/л). Формування часток срібла (до 100 нм) підтверджено методом рентгеноструктурного аналізу та IЧспектроскопії. Одержані колоїні розчини наночасток срібла сприяють формуванню менш потужної біоплівки за умов мікробної корозії низькокарбонової сталі, інічійованої сульфатвідновлювальними бактеріями роду Desulfomicrobium. Бактерії роду Desulfovibrio виявилися резистентними до наночасток срібла.

Ключові слова: плазмохімічний, наночастки, срібло, натрій альгінат, сульфатвідновлювальні бактерії, біокорозія. 